\title{
Cooperation between Ukraine and Kazakhstan in the Space Sector: Background, Regulatory Framework, and Further Development
}

\author{
Olexiy Drozd
}

Doctor of Law, Associate Professor, National Academy of Internal Affairs

(Kyiv, Ukraine)

E-mail: alex0674682444@gmail.com

https://orcid.org/0000-0002-4514-6594

Drozd, Olexiy (2020) Cooperation between Ukraine and Kazakhstan in the Space Sector: Background, Regulatory Framework, and Further Development. Advanced Space Law, Volume 5, 25-33. https://doi.org/10.29202/as1/2020/5/3

The article analyzes and studies theoretical and practical aspects of the relationship development of international scientific and technical cooperation between Ukraine and Kazakhstan, aimed at their improving, as a factor in expanding innovative, scientific, technical areas and increasing the competitiveness of economies in the context of globalization. The analysis of the current legal regulations of Ukraine and Kazakhstan on space activities enabled us to reveal the foundations of scientific and technological cooperation, as an essential component of international relations of our time. The theoretical and methodological approaches to the organization of scientific and technical collaboration are systematized. The modern specificities of bilateral cooperation are revealed, and the results and achievements of Kazakhstan and Ukraine in the space industry are presented.

Keywords: space, space activity, bilateral relations, scientific and technological cooperation, innovation, legal regulation, law.

Received: March 15, 2020; accepted: April 27, 2020

\section{Introduction}

Scientific and technological cooperation is an increasingly important and effective form of modern international relations. Considering the high rate of scientific and technological progress, no country, no matter how significant its potential in science and technology is, can fully satisfy its needs in advanced science and technology for the production of total

(C) Drozd, Olexiy, 2020 
scientific products, which are constantly changing and improving. Cooperation in creating high-tech products is the most important part of modern international relations. According to Sergey Krichevsky and Sergey Udartsev, “...When analyzing the history of space activities, the current situation and forecasting the future of the space state, the world community and all our civilization on Earth and beyond, the prospects of space humanity, we deal with complex conceptual, legal, socioenvironmental, digital and other models of the past, present and future" (Krichevsky \& Udartsev, 2019).

International scientific and technological cooperation is one of the forms of international economic cooperation, covering trade in licenses, performance of joint scientific developments, implementation of large technical projects, construction of enterprises and other objects, training of national personnel, exchange of general scientific and technological information, etc. (Dakhno, 2009: 201). This is a joint development of scientific and technological issues, mutual exchange of scientific achievements, experience, and training of highly qualified specialists.

Nowadays, all economies are assessed according to investments in education, science and technology, culture, and innovation. Knowledge, primarily scientifically based knowledge, is crucial to transforming the more and more complex challenges that society faces into opportunities for more sustainable development, achieving the Millennium Development Goals, and fulfilling other joint commitments.

Considering the relevance of this issue, the scientific community presents several concepts for the strategic development of scientific and technological cooperation: theories of economic growth (the relationship between science and industry, the impact of scientific and technological performance on economic development, innovation theories, the theory of stalemate in technology, exogenous and endogenous theories, new economic growth models) and the theory of increasing competitiveness through cooperation (functioning of commercial "ecosystems", "co-competition", the theory of intercompany cooperation, game theory) (Chernytska, 2009) and so on.

We suggest that the most progressive concept is the theory of "the knowledge triangle." This concept has gained popularity because it emphasizes an integrated (systemic) approach to the interlinkage between research, education, and innovation. In their work The Knowledge Triangle between Research, Education and Innovation (Unger \& Polt, 2017), Maximilian Unger and Wolfgang Polt define this interaction as follows:

1. Research and Education: interactions are reflected, for example, in the geographical and sectoral mobility of graduates, postgraduate training programs, fundamental and applied research as the foundation for measures to improve skill-matching between companies and graduates.

2. Research and Innovation: here, knowledge comes into focus, for example via a) public-private partnership models (e.g., clusters, science parks), b) the commercialization of publicly funded research, c) contract research and development services from universities for the industrial sector, d) university spinoffs and academic start-ups, e) knowledge and technology transfer offices (TTO), f) incubators, g) open innovation platforms.

3. Education and Innovation: Collaboration between actors is evaluated by considering the support for the development of an entrepreneurial culture (entrepreneurial spirit) in the framework of (academic) training programs (e.g., industry-focused doctoral programs) and the formation of appropriate competencies (business plan development, management, etc.). 
Cooperation between Ukraine and Kazakhstan in the Space Sector: Background, Regulatory Framework, and Further Development by Olexiy Drozd

Therefore, the globalization of scientific and technological relations, the development of the "knowledge" market as the main factor of economic growth of the country, the formation of the world market of innovative technologies gives grounds to argue that a new form of international economic relations, that is, international scientific and technological cooperation has been formed.

\section{International space law as the basis for the successful development of national space research projects}

Traditionally, the launch of Sputnik-1 in 1957 is believed as the beginning of space law and space legislation. However, issues of legal regulation of space exploration appeared much earlier. As soon as a person had the opportunity "to fly," rules for the use of airspace were required. Airspace and outer space have been related to international law only since the beginning of the 20th century. Namely, in 1902, the Wright Brothers made more than seven hundred flights. These are two American pilots, engineers, inventors, and pioneers of aviation, who are usually credited with inventing, constructing and piloting the world,s first aircraft. They tested a plane Flyer in the dunes of Kitty Hawk on December 17, 1903 (de Gouyon, 2019).

Since then, the rules for the use of airspace should be established.

The first rules were approved by the Paris Convention on the Regulation of Aerial Navigation (1919) (Convention, 1919) and subsequently by various other multilateral treaties. On 11 July 1922, the Paris Convention entered into force after it had been ratified by 14 countries, including the British Empire (consisting of seven states: Great Britain, Australia, Canada, India, Ireland, New Zealand, and the Union of South Africa) and France.

The Paris Convention was the first multinational rule governing air navigation. Article 1 establishes the complete and exclusive sovereignty of each State over the atmospheric space over its territory, putting an end to many years of disputes.

In this article, the history of space law will not be analyzed, but it should be noted that both at the beginning of the $20^{\text {th }}$ century and in the $21^{\text {st }}$ century, the issues of the "right" to outer space and resources are discussed from two perspectives: first, outer space belongs to all states; second, outer space does not belong to anyone.

According to the practice, nowadays, space law cannot establish rules that will be valid for a long time. Technological progress is developing so fast that existing legal standards adopted to regulate space exploration are becoming obsolete. Therefore, Michel Bourbonniere (Bourbonniere, 2005) argues that today the question is the adoption of global rules of conduct not to regulate technological progress, but to restore order in the competing human interests that arise from this progress.

Consequently, at the sessions of the Committee on the Peaceful Uses of Outer Space, the proposal to adopt the Code of Conduct in Outer Space was repeatedly voiced. The draft Code of Conduct in Outer Space is based on three basic principles: freedom for all to use outer space for peaceful purposes, maintaining peace, preserving the integrity and inviolability of space objects, and preserving the interests of all participants in space activities (COPUOS, 2010). However, despite the progressiveness, the draft Code has one significant drawback. That is, it shall not be mandatory, and its signing shall entail neither responsibility nor sanctions for these countries. 
The rapid development of space activities has revealed the shortage of a legal regime based on five existing treaties. It is required to fill in the gap to catch up decisively and urgently. The current legislation should be the basis for further movement gaining a foothold on new frontiers. The delegation welcomed everything done by the international community and supported the idea of creating favorable conditions for the formation of a single treaty on outer space (COPUOS, 2010).

\section{Background for establishing Ukrainian-Kazakh bilateral relations}

The Act of Independence of Ukraine of August 24, 1991, and the Appeal of the Verkhovna Rada of Ukraine "To Parliaments and Peoples of the World" (To the Parliaments, 1991) provide for the key objectives, areas, and priorities of the foreign policy of Ukraine, such as Ukraine is establishing a democratic, law-governed state; ensuring human rights and freedoms is a top priority. Ukraine will continue to abide by international law, guided by the Universal Declaration of Human Rights, the International Covenants on Human Rights ratified by Ukraine, and other relevant international instruments. Ukraine will strictly adhere to the norms of international law, guided by the Universal Declaration of Human Rights, the International Covenants on Human Rights, which Ukraine ratified, and other relevant international instruments. As one of the United Nations founding states, Ukraine, in full accordance with the purpose and principles of the UN Charter, will direct its foreign policy towards the consolidation of peace and security in the world, the intensification of international cooperation in solving environmental, energy, food and other global issues. Ukraine's foreign policy will be based on the international law principles (Pro proholoshennya, 1991).

Therefore, according to the legal regulations mentioned, Ukraine laid the foundation for productive cooperation with various states in strategically important sectors.

The past decade has shown that the principles of foreign policy, proclaimed at the beginning of the establishment of independence, have been consistently implemented in practice. As a result, Ukraine has become an important subject of world politics, which should be considered even by the great powers of today. Zbigniew Brzezinsk, a famous American political scientist, discussing geostrategic actors and geopolitical centres, estimates Ukraine as a new and important actor on the Eurasian chessboard, as a geopolitical pivot. He underlines that its very existence as an independent country helps to transform Russia. Without Ukraine, Russia can still strive for imperial status. Still, it would then become a predominantly Asian imperial state, more likely to be drawn into debilitating conflicts with aroused Central Asians (Brzezinski, 1997).

Therefore, the analysis of the formation of cooperation between the two countries, Ukraine and Kazakhstan, is of great importance. Considering that both countries have a favorable geopolitical position on the Eurasian continent, they do not want to be dependent on Russia and have the status of spacefaring nations.

The issues of development of the Ukrainian-Kazakhstan bilateral relations have not been studied enough yet by both Kazakh and Ukrainian scientists. The vast majority of publications are journalistic (separate articles in periodicals). Moreover, the bilateral relations between Ukraine and Kazakhstan in space are virtually non-existent.

The formation and development of bilateral Ukrainian-Kazakh relations took place under challenging conditions. Independent states were faced with a number of strategic missions that needed to be addressed as soon as possible. One of the most important tasks was to decide on 
Cooperation between Ukraine and Kazakhstan in the Space Sector: Background, Regulatory Framework, and Further Development by Olexiy Drozd

the concept of its foreign policy in order to become a full-fledged actor of international life as soon as possible.

The leadership of Ukraine has chosen a course for European and Euro-Atlantic integration, striving to maintain maximum contacts with a key partner in Central Asia, the Republic of Kazakhstan, which has chosen a multi-vector foreign policy, among which the main directions were the Russian Federation, China, the USA and the European Union. Both countries are located in the so-called buffer zones: Ukraine is between Russia and Europe integrated into the EU, the Republic of Kazakhstan is between Russia, China and the Islamic world (Tokar \& Ruban, 2016).

Ukraine was one of the first states to recognize Kazakhstan as an independent state immediately after its independence proclamation (December 16, 1991). Kazakhstan recognized Ukraine on December 23, 1991, and on July 23, 1992, diplomatic relations were established between the two countries. Political contacts at the highest level evidenced the political will and joint readiness of the two states to develop mutually beneficial cooperation in various sectors, to deepen it in the light of current geopolitical and geoeconomic processes and national interests. Also, the proximity of historical destinies has long been connecting these nations. In the difficult times of the democratic state establishment, both Ukraine and Kazakhstan managed to make annual summits traditional, almost every year, to discuss a wide range of issues of international and bilateral relations. Over the entire period of cooperation, a number of important documents were signed that formed a solid regulatory framework.

In addition to the grounds for close bilateral cooperation mentioned above, it should be noted that the Ukrainian diaspora in Kazakhstan is one of the largest, the third among all Ukrainian communities in the world. Today, almost 450 thousand ethnic Ukrainians live in Kazakhstan. It is the second-largest diaspora in Kazakhstan, settled throughout its territory, but the largest number of Ukrainians live in Akmola, Pavlodar, Karaganda, Kustanai regions (Zhumambaev, 2008).

Due to the peculiarity of economic development in Soviet times, a certain shortage of specialists and technologies in metalworking, machine building, aviation and space industries arose in Kazakhstan. Meanwhile, Ukraine has a powerful scientific and industrial base, a sufficient number of specialists, and a high level of education. Nowadays, 124 joint KazakhUkrainian enterprises operate in Kazakhstan.

Thus, the historical prerequisites for the establishment of Ukrainian-Kazakh bilateral relations include:

a) a common historical past, that is, both countries for a long time were the part of the Union of Soviet Socialist Republics and actually did not have state independence;

b) the geopolitical specificities of countries, that is, both countries are located in the so-called buffer zones: Ukraine is situated between Russia, and Europe integrated into the EU, the Republic of Kazakhstan is situated between Russia, China and the Islamic world;

c) the similar positions of the two countries on key issues of modern political development (to get rid of dependence on Russia, to be a full member of the Space Club, etc.), the absence of acute problems in bilateral relations;

d) the attempt to integrate into the global economic community through the development of an innovative economy, in particular, the space industry;

e) the possibility of sharing resources: while Ukraine is interested in the world's largest cosmodrome Baikonur, situated in Kazakhstan, Kazakhstan is interested in the scientific resources of Ukraine. 
Each state sets a goal to improve life, to predetermine new social positive changes on the basis of economic, political, and social development. Therefore, it is imperative to understand the strategic plan for the future based on the globalization processes of our time. Consequently, it is relevant to consider ways of productive development of cooperation between these countries.

\section{The Legal Framework for Bilateral Development between Ukraine and Kazakhstan in the Space Industry}

The key documents of bilateral development between Ukraine and Kazakhstan are: "Treaty on friendship and cooperation between Ukraine and the Republic of Kazakhstan" (1994) and "Agreement on economic cooperation for 1999-2009" (1999). It should be noted that the years 1994-1997 became an important stage in the development of the legal framework, when more than 30 bilateral documents were signed during mutual visits of the presidents of the two states, that is, almost half of the ones in effect (The legal framework, 2019).

The key documents that have regulated bilateral cooperation between the two countries in the space sector are:

1. "Agreement on the principles of cooperation between the Government of Ukraine and the Government of the Republic of Kazakhstan in the implementation of space activities" (Uhoda, 1994) of January 20, 1994. Accordingly, both countries recognized the need to share their resources to achieve their goals, such as a useful exploration and use of outer space, the preservation and development of a unique space infrastructure in the interests of the national economy and science, the international cooperation, and security of both states. In addition to its historical significance, this Agreement marked the beginning of a long and productive cooperation in the space sector.

2. "Agreement between the Government of the Republic of Kazakhstan and the Government of Ukraine on cooperation in the research and use of outer space" (Uhoda, 1997) of October 14, 1997. Ukraine ratified the Agreement by Law no. 104-XIV (104-14) of September 11, 1998, Kazakhstan ratified it by Law no. 22 of December 30, 1999. This Agreement primarily determined the legal framework for bilateral cooperation in the exploration and use of outer space. In addition, this regulatory act expanded the principles of bilateral cooperation in comparison with the 1994 Agreement. The parties agreed on: ensuring the rights of the Parties in proportion to their investments in the share of industrial and intellectual property created in the course of projects (work); preservation of state secrets and compliance with well-agreed confidentiality in joint activities; compliance with environmental legislation with the predominant effect of the legal acts of the State where joint space activities are carried out.

After the aggravation of the political situation in Ukraine (the beginning of the Revolution of Dignity, caused by the refusal of the country's political leadership to take a legislative course on European integration, growing corruption and excessive concentration of power in the hands of V. Yanukovych), as well as the annexation of Crimea by Russia and the "referendum" in Crimea, Kazakhstan was not able to take an unequivocal position, but advocated the early restoration of order and stability (Tokar \& Ruban, 2016). However, this did not affect bilateral relations between the countries. 
Cooperation between Ukraine and Kazakhstan in the Space Sector: Background, Regulatory Framework, and Further Development by Olexiy Drozd

The intensification of bilateral cooperation in the space sector occurred after a working visit of the President of Kazakhstan to Ukraine on December 22, 2014. Following negotiations, principal agreements on enhancing cooperation in the energy, engineering, aircraft manufacturing, space industries, and deepening cooperation in the military-technical sector were reached. They also discussed issues of cooperation in the space sector, in particular, the joinder of the Ukrainian Design Office Yuzhnoye, Yuzhmash and Khartron with the Kazakh capabilities, including the Baikonur Cosmodrome (Political, 2019).

In order to ensure the implementation of the high-level agreements and the implementation of various bilateral agreements, the Joint Interstate Ukrainian-Kazakh Commission for Economic Cooperation was created in 1996, following the meetings of which specific measures are planned to enhance mutually beneficial bilateral cooperation in various sectors. Moreover, the Minutes of the meeting provides for the priority areas for economic cooperation in the near future, such as the issues of studying and identifying new areas for cooperation in the space industry. The last meeting of this commission was held in 2018. After a telephone conversation between the President of Ukraine Petro Poroshenko and the head of Kazakhstan, Nursultan Nazarbayev, a meeting of the next interstate Ukrainian-Kazakh commission on economic cooperation was agreed to be held in 2019 (Ukraine, 2018), but to date it has not been held.

At the present stage, Ukrainian-Kazakh cooperation covers a large number of promising areas in strategic areas, such as space, military technology, aviation. Both countries have significant potentials in these areas, as well as in peaceful space exploration. The use of one of the best world cosmodromes Baikonur can successfully serve the purpose.

Besides, promising projects are the creation of ground infrastructure for a satellite navigation system, a scientific space system for studying the Earth's ionosphere, a space remote sensing system, participation in the creation of the World Space Observatory, cooperation in the training and advanced training of specialists for the Kazakhstan space industry in Ukraine.

Bilateral scientific and technical cooperation between Ukraine and Kazakhstan focuses on the introduction of advanced technologies in the industry. Moreover, Kazakhstan remains interested in using the capacities and deliveries of products of the military sector of Ukraine, including uncrewed aerial vehicles, aircraft training complexes, as well as carrying out modernization of the AN-2 and AN-2-100 aircraft.

\section{Conclusion}

Mandatory mechanisms for effective cooperation in the scientific and technological sector are a high level of costs for its development (at least 1\% of GDP) with a constant upward trend of the private sector share in it; modernization of the innovation infrastructure; active cooperation at the regional level in the framework of innovation clusters, technology parks, business incubators; transnationalization of innovation through participation in international scientific and technical programs; enhancing of international technological strategic alliances; increasing the role of small and medium innovative entrepreneurship. In this entire process, the State takes a lead role, that is, it shall stimulate measures for the creation and sustainable development of innovative structures, as a guarantee of strengthening the country's competitiveness.

Bilateral relations between Ukraine and Kazakhstan demonstrates the development of positive cooperation dynamics in rocket and aircraft construction and identifies a number of new promising areas of cooperation: rocket and space technology, new materials and land remote 
sensing, joint industrial ventures based on existing industries, etc. Considering that Ukraine has a significant number of advantages in rocket and aircraft manufacturing, for Kazakhstan, within the framework of cooperation, it is an opportunity to enter the world market in these industries due to the high potentials and the large number of available professional specialists of Ukraine. In contrast, Kazakhstan has a cosmodrome Baikonur for the development of space programs in our country.

\section{미] References}

Bourbonniere, Michel (2005) National-Security Law in Outer Space: The Interface of Exploration and Security, 70 J. Air L. \& Comm. 3. https://scholar.smu.edu/jalc/vol70/ iss $1 / 2 /$

Brzezinski, Zbigniew (1997) The Grand Chessboard: American Primacy and Its Geostrategic Imperatives. Basic Books.

Chernytska, Tetyana (2009) International Scientific and Technical Collaboration in Conditions of Globalization. National Economic University Vadym Hetman.

Convention on the Regulation of Aerial Navigation, Paris (1919) 11 LNTS 173; 1922 UKTS 2, Cmnd 1609; 1 Hudson 359; 13 Martens (3d) 61; (1923) 17 AJIL Supp. 195. Cf. "Draft International Convention on Aerial Navigation", Paris 1910, Appendix to the Report of the (UK) Civil Aerial Transport Committee, 1918 UKSP Vol. V, 17, Cmnd 9218: www. bopcris.ac.uk/imgall/ref8301_1_1.html

COPUOS/LEGAL/T.617 (2010) United Nations Peaceful Uses Committee. Unedited Transcript, June 11. https://www.unoosa.org/pdf/transcripts/copuos/COPUOS_T617R. pdf

Dakhno, I. (2009) Znachennya ta pravove rehulyuvannya mizhnarodnoho naukovotekhnichnoho spivrobitnytstva. Mizhnarodne ekonomichne pravo. Tsentr uchbovoyi literatury.

de Gouyon, Matignon Louis (2019) The Paris Convention of 1919. Space Legal Issues. https:// www.spacelegalissues.com/space-law-the-paris-convention-of-1919/

Krichevsky, Sergey and Sergey Udartsev (2019) Space State on Earth and Beyond: Philosophy, Models, Experience and Prospects. Philosophy and Cosmology, Volume 23, pp. 30-52. https://doi.org/10.29202/phil-cosm/23/4

Political cooperation between Ukraine and Kazakhstan (2019) Website of the Embassy of Ukraine in the Republic of Kazakhstan, 2019. https://kazakhstan.mfa.gov.ua/en/ ukraine-kz/diplomacy

Pro proholoshennya nezalezhnosti Ukrayiny (1991) Postanova Verkhovnoyi Rady USR vid 24.08.1991, № 1427-XII. https://zakon.rada.gov.ua/laws/main/1427-12

The Legal Framework Between Ukraine and Kazakhstan (2019) Website of the Embassy of Ukraine in the Republic of Kazakhstan. https://kazakhstan.mfa.gov.ua/ru/ukraine-kz/ legal-acts

Tokar, P., and S. Ruban (2016) The Main Directions of Cooperation Between Ukraine and Kazakhstan at the Modern Stage of its Development (2010-2016). Science Newsletter of the Uzhgorod University, Seriya "History", vol. 2 (35).

To the Parliaments and Peoples of the World (1991) Address of the Verkhovna Rada of Ukraine of 05.12.1991. https://zakon.rada.gov.ua/laws/main/1927-12?lang=en 
Uhoda pro pryntsypy spivrobitnytstva Uryadu Ukrayiny i Uryadu Respubliky Kazakhstan u zdiysnenni kosmichnoyi diyal'nosti (1994) Data pidpysannya: 20.01.1994. https:// zakon.rada.gov.ua/rada/show/398_041

Uhoda mizh Uryadom Ukrayiny ta Uryadom Respubliky Kazakhstan pro spivrobitnytstvo $v$ sferi doslidzhennya ta vykorystannya kosmichnoho prostoru (1997) vid 14.10.1997. № 398_026. https://zakon.rada.gov.ua/laws/show/398_026/card2\#Card

Ukraine and Kazakhstan will hold a meeting of the Commission on Economic Cooperation (2018) UNN - Ukrainian National News, December 26. https://www.unn.com. ua/en/news/1770062-ukrayina-ta-kazakhstan-provedut-zasidannya-komisiyi-zekonomichnogo-spivrobitnitstva

Unger, Maximilian and Wolfgang Polt (2017) The Knowledge Triangle between Research, Education and Innovation - A Conceptual Discussion. Foresight and STI Governance. vol. 11, no 2, pp. 10-26. https://doi.org/10.17323/2500-2597.2017.2.10.26

Zhumambaev, Amangeldy (2008) Kazakhstan and Ukraine: to a new stage in relations. Ukrrudprom, March 6. http://ukrrudprom.com/digest/dfdsfxz060308.html 